\title{
Encountering begpackers
}

Tolkach, Denis; Jørgensen, Matias Thuen; Pratt, Stephen ; Suntikul, Wantanee

Published in:

Tourism Recreation Research

DOI:

10.1080/02508281.2018.1511943

Publication date:

2019

Document Version

Peer reviewed version

Citation for published version (APA):

Tolkach, D., Jørgensen, M. T., Pratt, S., \& Suntikul, W. (2019). Encountering begpackers. Tourism Recreation Research, 44(1), 17-32. https://doi.org/10.1080/02508281.2018.1511943

\section{General rights}

Copyright and moral rights for the publications made accessible in the public portal are retained by the authors and/or other copyright owners and it is a condition of accessing publications that users recognise and abide by the legal requirements associated with these rights.

- Users may download and print one copy of any publication from the public portal for the purpose of private study or research.

- You may not further distribute the material or use it for any profit-making activity or commercial gain.

- You may freely distribute the URL identifying the publication in the public portal.

Take down policy

If you believe that this document breaches copyright please contact rucforsk@kb.dk providing details, and we will remove access to the work immediately and investigate your claim. 


\section{Title: ENCOUNTERING BEGPACKERS}

Authors: Dr. Denis Tolkach ${ }^{\mathrm{a}^{*}}$, Dr. Matias Thuen Jørgensen ${ }^{\mathrm{b}}$, Prof. Stephen Pratt ${ }^{\mathrm{c}}$, Dr. Wantanee Suntikul ${ }^{\mathrm{a}}$

${ }^{a}$ School of Hotel and Tourism Management, The Hong Kong Polytechnic University

17, Science Museum Road, East Tsim Sha Tsui, Kowloon, Hong Kong

*Corresponding Author: denis.tolkach@polyu.edu.hk; +852 34002294

${ }^{\mathrm{b}}$ Department of Social Sciences and Business, Roskilde University, Roskilde, Denmark

${ }^{c}$ School of Tourism and Hospitality Management, Faculty of Business and Economics, The University of the South Pacific, Suva, Fiji 


\title{
Encountering Begpackers
}

\begin{abstract}
'Begpacking' refers to the practice of tourists begging, busking or selling trinkets at their travel destinations to finance their travel. Instances of begpacking have recently caused condemnation in mainstream and social media, fuelled by the perception that begpackers come from the rich Western world to take advantage of host communities in Asia. We undertake exploratory research of this phenomenon via qualitative research with begpackers in situ, combining this with social experiments in which a researcher-begpacker simulates begpacking to seek out reactions from the host community. We use our findings to characterise and conceptualise begpackers, and to investigate the interaction between begpackers and the host community. Finally, we discuss differences in perception of the phenomenon by media, the local community and the begpackers themselves.
\end{abstract}

Keywords: Begging; Backpacking; Begpacking; Equity Theory; Social experiment; Hong Kong

\section{Introduction}

'Begpacking', a portmanteau of 'begging' and 'backpacking' is used to describe predominantly (though not exclusively) young tourists who beg, busk, perform or sell trinkets in public spaces of their travel destinations to fund their trips (Grira, 2017). Begpackers often either beg or busk behind a sign with a statement saying something like: 'Please help fund my travel.' Mainstream and social media have generally condemned this behaviour (Groundwater, 2017), citing a perception that these begpackers exhibit a sense of entitlement. Some commentators argue that these practices are unethical and reinforce racist and discriminatory attitudes of colonialism, since begpackers are often Caucasians travelling through Asia. For example, as quoted by Pouget (2017) "I think that this kind of behaviour shows how many people still look at the world with an orientalist view. They see Asia as an exotic place of spiritual discovery. This turns our continent into a caricature, a mystical land full of adventures or, in other words, a playground for white people. People come here on a journey of self-discovery, eager for exotic experiences. Sometimes, I want to ask them: what makes you think that this kind of behaviour is normal in Asia? Why don't you do the same thing at home?" Others, even in the developed cities, such as Singapore and Hong Kong, highlight hypocrisy as these travellers are perceived to arrive from more affluent parts of the world with intentions to take advantage of the generosity of local host communities, rather than advance their well-being through hard-work. Groundwater (2017) comments: "How can any backpacker be self-entitled enough to sit there on the street with their hand out, ignoring the incredible amount of privilege that got them there in the first place, asking residents of developing countries to donate to the cause of their own enjoyment? How can people be so idiotic?" Begging is perceived to be necessary in cases of poverty, sickness or homelessness, rather than a method to fund international travel (Pleasance, 2017). It is worth noting that none of the begpackers interviewed for this study mentioned the term 'begpacking' 

activities undertaken on the street. We adopt the term begpacker, because this term is used in the mainstream media and accurately encompasses this type of travel.

To date, there has been scant research on tourism and the issue of begging. Previous studies have focussed mainly on tourists' perception of begging among the local community of their destinations. Begging is typically perceived to be a detrimental characteristic of tourist destinations (Henry, 2009; Smith, 2005). A literature search has revealed no previous academic research undertaken on the topic of tourists begging/busking. Given increasing public and media awareness and criticism of begpackers, this research undertakes an exploratory investigation into this phenomenon. The aims of this research are: to create a base of knowledge and a conceptualisation of the begpacking phenomenon and to explore attitudes residents have towards begpackers.

Very little reliable information is available about begpackers: their origin, their number, and their travel patterns. None of the news media or officials mention any statistics. Nevertheless, it is evident that the phenomenon has generated public interest and controversy, especially in Asia. For example, begpacking has been a widely observed and discussed phenomenon in Hong Kong. This is reflected in (social) media discussions (e.g. Grundy, 2017; Yu, 2015 and Wordie, 2017), as well as in general media reporting on the phenomenon, where Hong Kong is mentioned as a primary destination for begpackers (e.g. Pleasance, 2017 and Pouget, 2017). Hong Kong is an affluent Asian city, therefore stereotypical power relations between 'entitled' Western travellers and 'exotic' local residents do not necessarily apply. Who exactly the begpackers in Hong Kong are is however unknown, as are the attitudes that local residents have towards them. Moreover, Hong Kong is a transport hub and has relatively relaxed visa policies, which enables the researchers to recruit participants who have visited various parts of Asia. Therefore, Hong Kong was chosen as an appropriate context for this study. The methods for this research study are qualitative semi-structured interviews with begpackers, as well as social experiments, in which a member of the research team simulates begpacking, while other members of the research team intercept passers-by and document their reactions to this simulated begpacking.

\section{From tramping to backpacking and back}

The present study seeks to understand the begpacking phenomenon, a style of travelling which involves travellers begging or busking to fund their travel. While begging and travelling might at first appear as two very different activities, they have been intertwined for centuries. Adler (1985) suggests that modern tourism has roots in two distinct traditions of travel: one is the Grand Tour of affluent European youth primarily for education, another is travel of American and European working-class youth in search of work. The latter practice is commonly known as tramping. Tramps, vagabonds, travellers and hobos are terms often used to define a class of people in the nineteenth and early twentieth centuries who travelled, undertook temporary work and had no permanent residence. While tramping was often a necessity due to scarcity and seasonality of employment, wanderlust also appears to have driven many tramps (Adler, 1985). 
Cohen (2004) suggests 'drifting' as the subsequent wave of long-term travel. Drifters were mostly Western young people who felt alienated in the societies of their origin and travelled to gain new perspectives on their lives and to explore other worlds. Cohen (2004) argues that drifting is a postmodern phenomenon. Drifters go off the beaten track, tend not to connect with tourist-oriented infrastructure and businesses and value freedom from fixed itineraries. Drifters are tramps, not out of necessity, but by choice. It is important to note that drifters may reluctantly take up odd-jobs to fund their travel. Cohen (1973) suggests that drifters may beg, scavenge, share food and lodging with acquaintances. Because drifters lived more like local residents using local infrastructure and services - they became more insulated from the mass tourism bubble. Weber (2001) compares adventure travellers and drifters and refers to Maslow's hierarchy of needs as one of the approaches used to understand motivations for these travellers. She concludes that self-actualisation is important for both groups, albeit adventure travellers require satisfaction of basic needs, such as safety, more than the drifters.

In the late 1970s, backpackers emerged as an institutionalised segment of youth travellers who imitate drifters, but commonly use services and infrastructures designated for them (Cohen, 2004). However, Uriely (2001) groups tramping, drifting and backpacking together as noninstitutionalised working tourists. Backpackers can be distinguished from conventional travellers based on accommodation type, social interaction, type of schedule, length of stay and type of activities (Loker-Murphy \& Pearce, 1995). Backpackers typically stay at youth hostels and budget accommodation. They tend to form enclaves or assemblages congregating at popular accommodations and establishments servicing backpacker markets (Cohen, 2018). Their typical travel motivation is experience seeking (Richards \& Wilson, 2004). Backpackers undertake adventurous activities, venture out from the typical tourist zones, have flexible holiday schedules, stay longer at destinations and are likely to interact with other travellers and local residents (Hampton, 1998; Mohsin \& Ryan, 2003).Backpackers typically have vivid memories of their travels and suggest they have been transformed by them (Collins-Kreiner, Yonay \& Even, 2018).

Backpackers are increasingly discussed through a sustainability lens. Backpackers are often perceived as a low-impact travellers interested in environmental education, local consumption, interaction with local residents and experiencing local culture (Nok, Suntikul, Agyeiwaah, \& Tolkach, 2017). Moreover, digital technologies play an increasingly important role in how backpackers travel (Cohen, 2018; Richards, 2015). Due to an expansion of literature on backpacking, incongruences in the criteria used to define backpackers have emerged. Thus, Dayour, Kimbu \& Park (2017) call for a reconceptualization of the term.

The present paper explores the extent to which begpacking resembles the aforementioned styles of travel, namely tramping, drifting and backpacking, and in what ways it appears to be a distinct new style of travel, separating them from previously defined types of travellers. 


\section{Tourism and begging}

Begging has been a common phenomenon across time and cultures (Wardhaugh, 2009). However, there is little research on the nexus between tourism and begging, which is surprising, given that beggars are often found in areas frequented by tourists (Weber \& Bowling, 2008). Existing literature investigates tourists' perceptions and reactions to begging among segments of the local community (Qiao, Chen, \& Prideaux, 2017). As with other literature (Adriaenssens \& Hendrickx, 2011), we take a broad definition of begging as informal economic activity that involves asking a stranger for a donation, on the basis of being poor and in need of charitable donations. This begging might involve the pretence of selling small items or musical or nonmusical performing, in return for financial compensation that may have little to do with the value of the item (Brito, 2013; Simpson, 2011).

Andriotis (2016) provides a useful typology of beggars, and of tourists' interaction with beggars. He classifies beggars into three categories: classical beggars, who wait passively for alms, usually in the one place, without performing; table-to-table beggars, who venture from place to place selling small items for money; and performing beggars who play a musical instrument or perform a drama for money. The performances of beggars in the last category are usually somewhat token and often of variable quality. Andriotis (2016) also found four categories of tourists' reaction to beggars, ranging from apathetic to supportive and sympathetic to harassed. The largest proportion of tourists walked past beggars without noticing them. Supportive tourists gave money voluntarily with little persuasion needed by the beggars. A small proportion of tourists were sympathetic to beggars. The harassed tourists were annoyed at being approached.

Qiao et al. (2017) examine tourists' reactions to beggars in China, finding tourists to be generally supportive. They will often provide a donation, but refuse any further communication with beggars. Qiao et al. (2017) also develop a typology of beggars, based on others' work (Andriotis, 2016; Henry, 2009; Lozanski, 2013). The types of beggars can be summarized by three factors: demography (older, adult, children); approach (passive, aggressive); and technique (story-telling, sitting, selling items, disability, performance).

In general, begging is seen as problematic (Lozanski, 2013) and as detrimental to a destination's image (Henry, 2009; Smith, 2005). The presence of large numbers of beggars might discourage tourism for two reasons. Firstly, tourists might not want to be reminded of poverty while on their trip and secondly, they might associate the presence of beggars with increased crime in that location (Smith, 2005).

The scarce research on tourism and begging has centred on tourists' interaction with and reactions to local beggars. This research examines a reverse phenomenon: tourists begging / busking while travelling. To the authors' best knowledge, there have been no prior studies undertaken with an explicit focus on international travellers begging during their journeys. 


\section{Equity Theory as a lens to understand Begpacking}

Many tourism studies have used social exchange theory to assess the social impacts of tourism on host communities (Ap, 1990). Social exchange theory states that residents undertake an implicit cost-benefit analysis by which they are willing to participate in a host-guest exchange as long as their perceived benefits outweigh their perceived costs. Other scholars have examined social-cultural impacts of tourism in terms of emotional solidarity whereby residents' support for tourism depends on the extent of similarity and shared understanding between themselves and tourists (Woosnam \& Norman, 2010). Further, Harrill's Growth Theory (2004) proposes that residents who profit the most from tourism will demonstrate greater support for tourism development. When operationalized, these commonly applied frameworks tend to ask residents' opinions in broad areas, such as the extent to which tourism has contributed to the economy, or the extent to which tourism has resulted in environmental degradation.

While residents can think more broadly on the impacts of tourism, as individuals, personal dayto-day interactions can directly influence residents' perceptions of tourists. This research uses equity theory as a lens through which to analyze encounters between tourists and the local community. Equity theory states that a person will judge an interaction as fair if the ratio of what they receive (an outcome) compared to the effort (input such as time or money) they expend is equal to a relative or reference outcome-to-input ratio (van den Bos, 2001). Burnstein and Katz (1972) contend that equity theory takes into account the relationship between two ratios: (1) the benefit an individual receives (outcome) for his/her performance relative to the investment (input) he/she makes; and (2) the relative benefit others earned (outcome), in relation to the investment they make (input). While this alludes to social exchange theory, in terms of costbenefit analysis, equity theory focuses on an individual level. It is not just the rewards or the outcome being different that leads to a perception of injustice but the relation between the ratio of rewards to effort that leads to a feeling of relative deprivation (Adams, 1965). An injustice is experienced when there is a discrepancy between what is perceived should occur and what does occur. Adams (1965) notes that the theoretical concept of outcome-to-input ratios can be applied in many social settings with which an exchange takes place, explicitly or implicitly. Many previous applications of equity theory have been in employer-employee relationships. Nevertheless, the begpacking context is equally applicable and as yet, unexplored.

Equity theorists have outlined some of the reactions of the harm-doer and of the victim. Harmdoers would be those individuals who receive an outcome greater than their input, taking into account the relative outcome and input of those they interacted with. An individual is a victim if what they receive (outcome) in an exchange is less than they contribute with their resources relative to the benefits received and effort expended by the other individual. Walster, Berscheid, and Walster (1973) notes that harm-doers might engage in neutralization techniques. Neutralization is a process through which individuals rationalize their deviant behaviours by excusing themselves or blaming other people. Neutralization helps individuals cope with decision conflict and psychological tensions such as guilt and blame (Chatzidakis, Hibbert, \& Smith, 2006). Common neutralization techniques include the denial of injury or minimization of the victim's suffering; denial of responsibility for the act; and derogation of the victim / 

the victims of their actions may also engage in similarly unethical activities.

When a victim decides they have experienced an injustice, the default behavioural reaction is to do nothing (Tyler, 2008). But this inaction can result in psychological distress such as anger or depression. This, in turn, might manifest itself into passive-aggressive behaviour such as posting the injustice on social media, rather than confronting their wrong-doer. The victim may also physically leave the situation to avoid the wrong-doer. Restoration of equity by victims can take various forms. One form of restoration is retaliation whereby the victim sometimes takes matters into their own hands to restore equity in the relationship (Walster et al., 1973). A second reaction is forgiveness whereby the victim may forgive the harm-doer, especially if the harm-doer was ignorant of their wrong-doing or the wrong-doer apologizes. There may also be intervention by outside parities, such as law enforcement agencies, particularly if a crime was committed.

In the case of begpackers, the media reports outlined earlier in the article suggest that the local community perceives an unfair exchange between begpackers and their hosts. The return that the begpackers received from the destination (money, a place to temporarily reside, the use of public services) is significantly greater than the effort and contribution these types of travellers are giving to the destination. In this research, we seek to determine whether the local community and begpackers themselves perceive there to be an equitable exchange between the two parties. We report common neutralization techniques from the begpackers in response to perceived inequity of exchange. Further, when passers-by feel they have experienced an unjust exchange with these travellers, we note their behavioural reaction. Do they just ignore begpackers or do they express their dissatisfaction, either verbally or physically?

\section{Methods and Data}

The present paper adopts a qualitative inductive exploratory methodology (Veal, 2006). The aim of this paper is to create a base of knowledge about the begpacking phenomenon, which has value on its own, but also creates a platform on which other researchers may build. The evasiveness of begpackers meant that it was not possible, nor sensible, to do a large-scale study. The researchers instead aimed to create a level of validity and reliability by triangulating data from different sources (Golafshani, 2003; Patton, 2001). These data sources include social experiments, which allowed for participant observation and on-site interviews with local residents, as well as qualitative semi-structured interviews with begpackers.

Both types of data collection rely on in-depth semi-structured interviews (Kvale \& Brinkmann, 2008; Russel, 2006) as primary means for data collection. Semi-structured interviews offer the opportunity to gain a deep understanding of the particular phenomenon, allowing interviewees to reconstruct their experiences and practices in detail (Seidman, 2005). A combination of convenience sampling and purposeful sampling (Maxwell, 2004; Patton, 2001) was used to select interviewees. This sampling method was chosen because the goal of the data collection was to maximize depth and richness of data to address the research questions (Kuzel, 1992). 
One of the two data collection methods was qualitative semi-structured interviews with begpackers. Questions were asked about the reasons they choose to do begging and busking activities during their travel, their thoughts on the ethics of doing so, and the reactions to their begpacking activities that they had observed from their surroundings. The recruitment of begpackers for interviewing was difficult, one of the reasons being the illegal status of begging in Hong Kong, thus begpackers were reluctant to be interviewed. The researchers attempted to reach begpackers through online forums, but with no luck. Instead a more direct approach was taken, in which the researchers looked for begpackers in the city. If one was spotted, the researchers would approach him or her directly, explain the project and ask for their participation in an interview, which would then be set up for a later time. The researchers continued this type of search between May 2017 and January 2018. Many of the encountered begpackers refused to participate, but some agreed to meet for an interview. They were offered, and accepted a meal for their participation.

Overall, eight begpackers agreed to be interviewed in Hong Kong. To the researchers' surprise and contrary to reports in the mainstream media (Groundwater, 2017; Pouget, 2017), all interviewees were travellers from countries of the former Soviet Union, such as Kazakhstan, Russia and Ukraine. As the search for interviewees progressed on the streets of Hong Kong and through online forums, the researchers observed that most begpackers in Hong Kong came from the aforementioned three countries of the former Soviet Union. In and of itself, this was an interesting finding, which is further discussed in the findings section, because the news media reports suggest begpackers were from developed West European countries (e.g. Grira, 2017; Grundy, 2017; Pouget, 2017). Three interviews with begpackers were conducted in English and five were conducted in Russian by a native Russian speaking member of the research group, who also translated and transcribed these interviews into English. On average each interview took 47 minutes. The interviews were recorded and meaning condensation was subsequently conducted for each of them. Table 1 provides an overview of respondents. Researchers would have preferred to include a larger number of interviewees, but decided to stop the data-collection due to the following reasons: (1) enough insights had been gained to generate interesting and relevant exploratory findings, (2) the information from begpackers is supplemented with information gained through the experiments and (3) the time required to add only a few more interviews (at the rate of about one interview per month) was not worth the subsequent aging of the collected data considering the media attention given to the begpacker phenomenon. 
Table 1: Respondent overview

\begin{tabular}{|c|c|c|c|c|c|c|c|}
\hline $\begin{array}{l}\text { Respondent } \\
\#\end{array}$ & Nationality & Age & Sex & Education & $\begin{array}{l}\text { Previous } \\
\text { travel } \\
\text { experience }\end{array}$ & $\begin{array}{l}\text { Activities } \\
\text { undertaken to } \\
\text { fund travel }\end{array}$ & $\begin{array}{l}\text { Current } \\
\text { travel } \\
\text { length }\end{array}$ \\
\hline 1 & Ukraine & 29 & Female & $\begin{array}{l}\text { Higher education, Law } \\
\text { degree }\end{array}$ & $\begin{array}{l}\text { Resort } \\
\text { holiday in } \\
\text { Bali }\end{array}$ & Selling photos & $\begin{array}{l}11 \\
\text { months }\end{array}$ \\
\hline 2 & Kazakhstan & 26 & Male & $\begin{array}{l}\text { Higher education, } \\
\text { Engineering degree }\end{array}$ & $\begin{array}{l}\text { Russia } \\
\text { (visiting } \\
\text { friends \& } \\
\text { relatives), } \\
\text { work in the } \\
\text { USA }\end{array}$ & $\begin{array}{l}\text { Busking: } \\
\text { playing } \\
\text { guitar; selling } \\
\text { photos }\end{array}$ & $\begin{array}{l}1 \text { year } 4 \\
\text { months }\end{array}$ \\
\hline 3 & Russia & 26 & Male & $\begin{array}{l}\text { Incomplete higher } \\
\text { education, } \\
\text { Accounting/Marketing } \\
\text { degree }\end{array}$ & $\begin{array}{l}\text { Russia, } \\
\text { China, Hong } \\
\text { Kong }\end{array}$ & $\begin{array}{l}\text { Standing with } \\
\text { a sign }\end{array}$ & $\begin{array}{l}10 \\
\text { months }\end{array}$ \\
\hline 4 & Ukraine & 31 & Male & $\begin{array}{l}\text { Higher education, } \\
\text { Railway Engineering } \\
\text { degree }\end{array}$ & $\begin{array}{l}\text { Domestic } \\
\text { travel, } \\
\text { Belarus, } \\
\text { Russia } \\
\end{array}$ & $\begin{array}{l}\text { Busking: } \\
\text { playing guitar }\end{array}$ & $\begin{array}{l}2 \text { years } \\
9 \\
\text { months }\end{array}$ \\
\hline 5 & Russia & 39 & Male & Higher education & $\begin{array}{l}\text { Various } \\
\text { packaged } \\
\text { tours }\end{array}$ & $\begin{array}{l}\text { Standing with } \\
\text { a sign }\end{array}$ & 20 days \\
\hline 6 & Russia & 28 & Female & $\begin{array}{l}\text { Higher education, } \\
\text { Construction } \\
\text { management }\end{array}$ & \multirow{2}{*}{$\begin{array}{l}\text { Italy, } \\
\text { Slovakia, } \\
\text { Turkey, } \\
\text { Egypt, Sri } \\
\text { Lanka, } \\
\text { Thailand }\end{array}$} & \multirow{2}{*}{$\begin{array}{l}\text { Busking: } \\
\text { playing a } \\
\text { handpan and } \\
\text { an African } \\
\text { drum }\end{array}$} & \multirow{2}{*}{2 years } \\
\hline 7 & Ukraine & 29 & Male & $\begin{array}{l}\text { Higher education, } \\
\text { International } \\
\text { economics }\end{array}$ & & & \\
\hline 8 & Ukraine & 31 & Male & Master of Journalism & $\begin{array}{l}\text { Sri Lanka, } \\
\text { Russia }\end{array}$ & $\begin{array}{l}\text { Busking: } \\
\text { playing } \\
\text { saxophone; } \\
\text { selling } \\
\text { trinkets }\end{array}$ & $\begin{array}{l}16 \\
\text { months }\end{array}$ \\
\hline
\end{tabular}

Six interviewees were male, while two were female. Interviewees were between 26 and 39 years old. Their previous travel experiences varied. To fund their travel four respondents were busking, two were selling photos and two were just standing with a sign asking for money. At the time of the interviews, interviewees had travelled for between 20 days and almost three years. Most had already travelled for more than 9 months. Most had travelled through China and Southeast Asia, although itineraries varied.

The second data-collection method was social experiments. The aim of these was to observe local people's reactions to begpackers; to observe whether there was a difference, in reactions and donations, between busking (in this case playing simple songs on an instrument) and begging; and finally to get on-site reactions from those people who give money to begpackers and those who do not. In order to do so, the researchers recreated a realistic begpacker scenario 
by dressing a Caucasian member of the research group in typical 'backpacker clothes' and equipping him with a ukulele and a sign with a statement resembling 'Please help me travel the world' in Chinese and/or English (See Figure 1). The message as well as the language (English and Chinese) varied between each experiment. This researcher then acted as a begpacker in different locations in Hong Kong, where the researchers had previously observed begpackers in action. Another member of the research group was tasked as the observer and interviewer. This researcher observed the reactions of the people passing, initially as a concealed observer. In cases where passers-by gave money to the begpacker-researcher, the observer-interviewer revealed him/herself, explained the experiment, returned the money given, and asked whether the person was willing to participate in a short interview. The observer-interviewer would also confront people who had a visible reaction to the begpacker-researcher but did not give money, to interview them about their reaction. The research team went out to perform these experiments on four occasions, for about one hour each time. Interviews were conducted in English.

Figure 1: The researcher-begpacker busking in the streets of Hong Kong

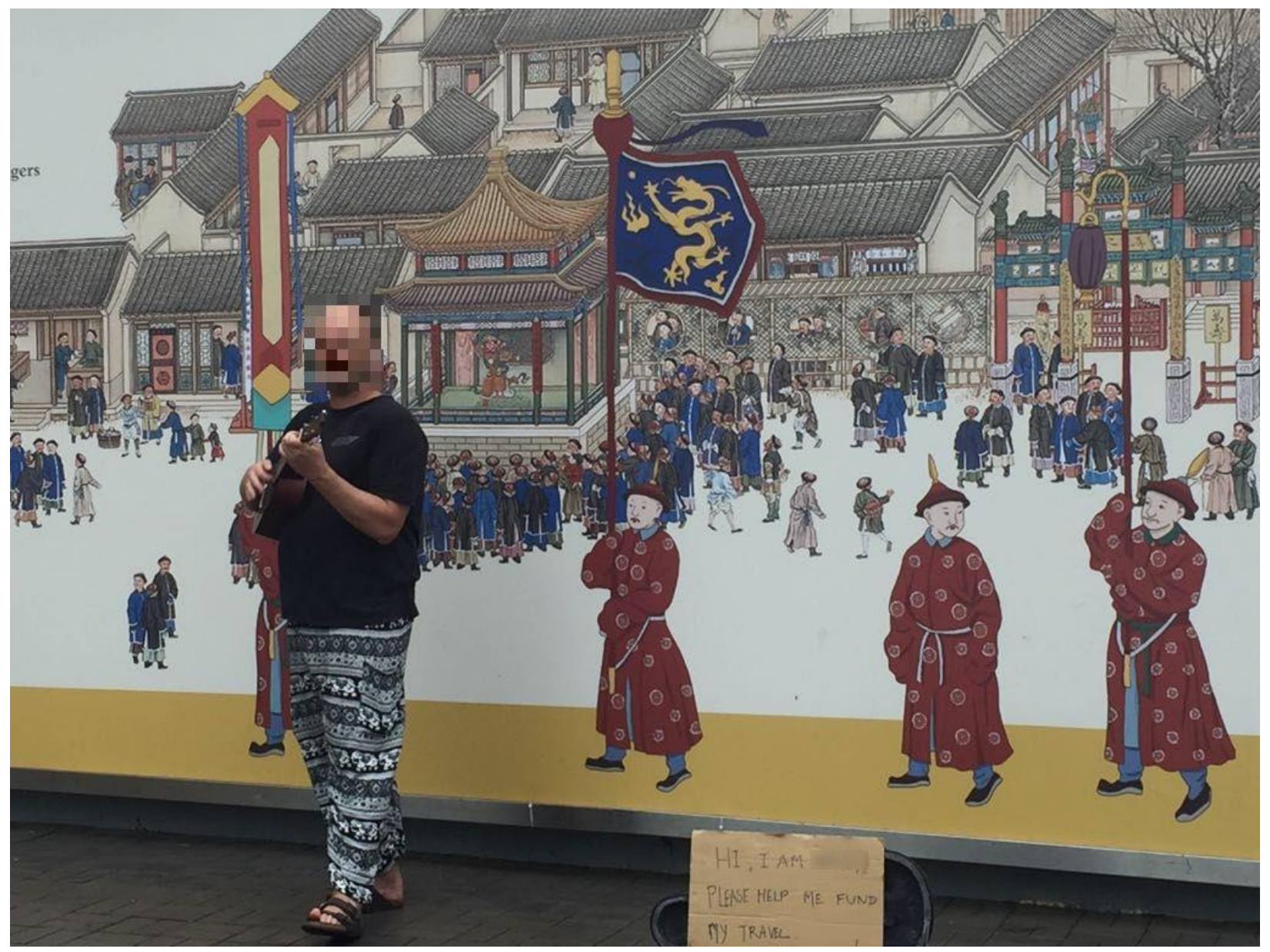

Source: Authors

Saturation was reached after 30 interviews of passers-by. At that point a sufficient number of interviewees who donated funds for the researcher-begpacker's travel $(n=12)$ was collected to 
contrast with those interviewees who did not donate money $(n=18)$. These interviews were conducted on the spot and on average lasted 9 minutes each. Notes were taken to document the statements made in response to the interview questions. Twenty one of those intercepted were Hong Kong residents and nine were from elsewhere, either expatriates living in Hong Kong or tourists. Expatriates and tourists came from countries including Canada, Mainland China, the Netherlands, New Zealand, the Philippines and UK. Interviewees ranged in age from 18 to 70, with an average age of 38 years. There was an equal mix of genders and a variety of education levels: eight interviewees were high school graduates, four had postgraduate qualifications and the remainder were completing or had completed their Bachelor's degree. All but six interviewees had some international travel experience in the past 12 months. Seven had been backpacking previously and seven had undertaken fundraising previously to raise money for a project, such as a school trip. While not necessarily generalizable to the whole population, the interviewees sampled in this social experiment represent a mix of genders, ages, education levels and travel experiences.

These experiments may prompt some ethical questions. In conducting the data collection, the researchers were aware at all times of potential ethical issues and took precautions to avoid these. For example, it was ensured that all money given as part of the experiments was returned and ethical clearance was gained through the researchers' institution's ethics committee to make sure that the data collection approach and materials passed ethical standards.

\section{Findings}

\section{Begpacker characteristics}

\section{Travel Planning}

None of the respondents had a detailed plan or itinerary when they left their home country. One respondent planned to travel around the world in one year (R8), but now he realises it might take three years. Generally, they also did not have a plan on how to fund their travels. Respondents varied in how prepared they were to beg or busk during their trip, when they started travelling. Only one respondent planned on making money by standing in the street with a sign:

\section{In fact, I had no money already when I left Russia to here. Of course, other than purchasing a flight ticket... I didn't have money, but my friend told me about this way of making money during the trip. And I can travel longer and more when I travel like that. (R5)}

Other respondents explained that they had money when they left, but expected to somehow fund their travels during the trip (R2, 6, 7 and 8). Others explained that the idea or necessity of begging or busking had come up during the trip, when they ran out of funds (R3 and 4). Figure 2 shows a photo of a map carried and displayed by one of the interviewees, visualising his travel route to passers-by. 
Figure 2: A photograph of one respondent's travel route that he has on display while busking

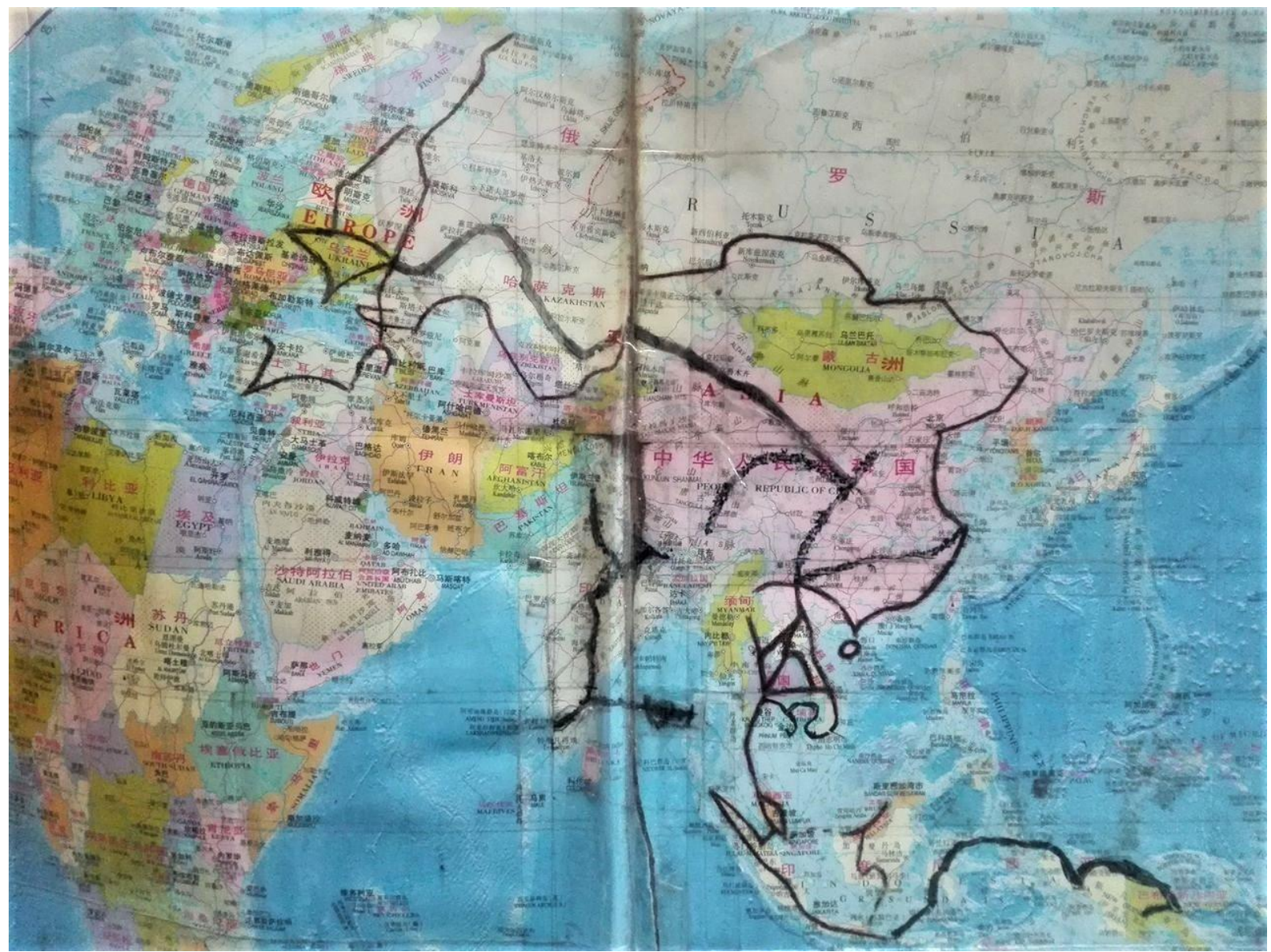

Source: Authors

All respondents except one (R8) were influenced to ask for money by people they knew from home or met while travelling. On- and offline word-of-mouth was the primary sources for information on how to travel on a budget and on how to fund the trip while travelling. One respondent described how he started funding his travel through asking for money on the street:

... I had problems with visa, because I had no money to get out of Hong Kong, to go to Macao. My visa expired. Then I met same slackers like me, just with more experience. They were selling photographs, they already knew what to do if you are in a foreign country without money. I didn't have photographs, and I had no money to buy food and I was sleeping in McDonald's. So, they said: 'just write on a piece of cardboard that you are travelling and you have no money, and just try your luck, what else can you do?' I never thought about that before, especially in a foreign country. I wrote: 'Hi! My name is ... Hong Kong is amazing, but very expensive. I spent all my money, but I want to continue travelling. Please help'... And it turned out to be quite profitable... After 6 hours 
Overall, the begpackers travel planning can be described as spontaneous and peer-influenced. They do not plan ahead and prefer to react to the given situation. Begpackers' travel itineraries are highly affected by their financial situation, because financial solvency is a requirement to acquire visas for many destinations.

\section{Travel Funding}

The respondents were either busking, selling photos and bracelets or simply standing with a sign in order to raise money to fund their travel. Respondents' opinions on whether there is a difference between these different activities were divided. Those who were busking or selling photos did not like people simply asking for money with a sign, arguing that you need to give something in exchange (R1, 2, 4 and 8). Others argued:

If you just beg, it doesn't lead to personal development, you don't learn anything... If you are not a musician, do something else then. But it's still better than just standing with a sign. Do whatever you can. Try to find your talent and develop your skill. (R6 and 7).

The respondents who were begging by standing with a sign admitted that they did not have any particular talent with which they could support their begging. One respondent stated that he was asking for money with a sign because foreigners are not allowed to work in Hong Kong (R5). Another argued that he did not see the difference, as busking or selling photos is only a pretext to ask for money (R3). However, the same respondent expressed that giving back is important, claiming that he was giving back positive emotions, as he always smiles while standing with a sign. Another respondent also stressed the importance of 'giving back' (R2). He provided the following example of how he tries to give back:

I travelled through all Laos. I've seen a lot of poverty in villages there. They don't have basics, no education, live in between cities. I made a video so that people could send money, things, books. Especially for children. They have so many children there. Then people started to send things from Europe, Russia, Laos. Some locals in Laos were surprised that there are such poor conditions in the country... This is what I want to do. I want to open people's eyes to what is happening around them. (R2)

In essence, all interviewed begpackers were aware of the importance of an equitable exchange. Some neutralised their behaviour by describing their inability to contribute more, for example due to lack of talent or lack of work permit. Others suggested that the exchange is not necessary between the same two individuals: if one person helps another person and that person in turn helps a third person at a later time, this is still an equitable exchange even though the first person does not benefit.

The respondents did not have detailed plans on where to busk or beg. In Hong Kong, the city centre appears to be more popular, although the respondents stated that they travel and busk in 
different parts of the city (R2, 4, 6 and 7). Begpackers generally look for relatively quiet places where they can be noticed, and, if they play music, heard. A number of respondents stressed that that they do not want to cause obstruction as they realise that space is limited in Hong Kong (R2, $3,4,6$ and 7). One respondent was very strategic in his choice of place:

It was obvious to me that it is better to stand somewhere, where people have money, where people are travelling, so they will understand what you want... There are many hotels [in my preferred spot]. So, people are more relaxed. If a person is rushing home after work, he won't bother... I don't like standing in places where I am not alone, because if there are several people the amount of money doesn't divide on the number of people. The total amount goes down, and the amount to each person falls as well. (R3)

Figure 3 shows an example of a begpacker's sign stating: 'Hello. I am ... from Russia. I am travelling in Asia for twelve months, Hong Kong is a very unique place, but the standard of living is very high. I no longer have travel money to continue my trip. Hope you can help'.

Figure 3: Example of a begpacker's sign

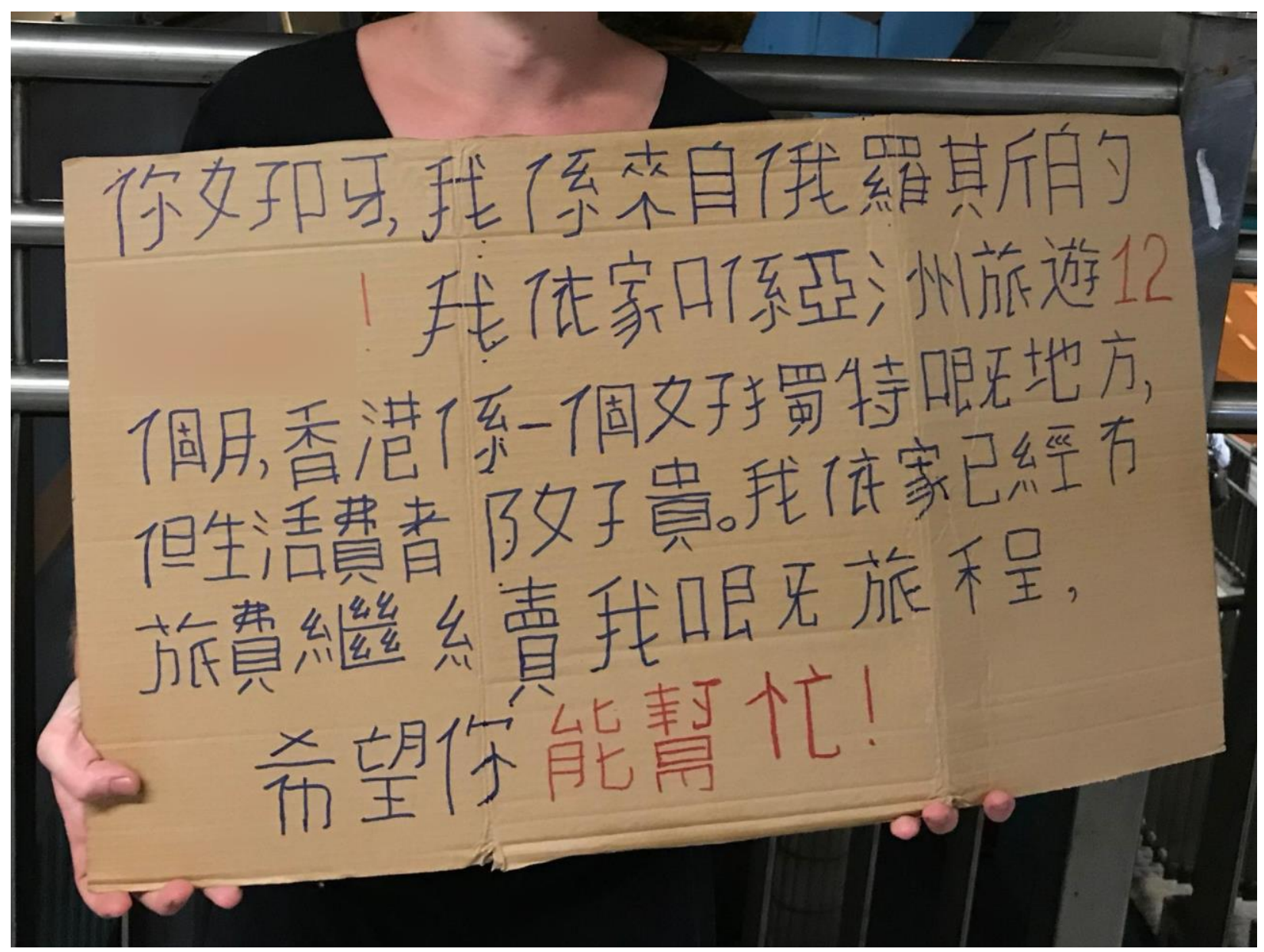

Source: Authors 

music set that they play each day (R6 and 7), others spent 3 to 4 hours per day busking on average, while another would spend more than five hours per day (R3). The amount of money earned depends on the time spent and therefore varies between respondents. On average respondents were able to earn more than HK\$300 ( US\$38) per day, with some reporting that they were able to make much more. One respondent made an average of HK\$200 ( US\$26) per hour (R3). Considering that he spent five hours asking for money, his daily income would be around $\mathrm{HK} \$ 1,000$ ( $\sim \mathrm{US} \$ 128)$. Another respondent (R8) explained that his income varies greatly, between HK\$80 ( US\$10) for two hours and HK\$1,400 ( US\$179) for five hours of playing. Since daily expenses of a begpacker are approximately HK\$200 ( US\$26) according to the interviewees, it is possible for begpackers in Hong Kong to save for further travel. For most respondents (except R5) Hong Kong was not the only place to beg or busk, therefore they could compare their experiences with other destinations, e.g. Indonesia, Malaysia and Thailand). One respondent explained that despite being more expensive, Hong Kong is more profitable than destinations in Southeast Asia (R4). The respondent perceived Hong Kong to be more profitable because the wages and salaries of Hong Kong residents were higher and thus enabled residents to give more, compared to lower-income countries in South-east Asia. It is worth noting that the funds acquired by these begpackers are much higher than the minimum hourly wage in Hong Kong (HK\$34.50 or $\sim$ US\$4.43).

Common for all interviewed begpackers is that they have different ways of attaching meaning to what they do. All of them argue that it is important to give something back to the local community, whether it is a performance, time spent on philanthropic activities or simply a smile. The time spent begging or busking varies, so does the income gained from it. Commonly, it seems that begpacking does require a time investment to develop a skill that warrants a monetary return, but if the investment is made, the reward may also be considerable when compared to low paying jobs in the local community as well as in the home countries of the begpackers.

\section{Living}

Various accommodation strategies are employed by begpackers. Respondents were staying in hostels, camping or couchsurfing. One respondent even slept on a rooftop (R8). In Hong Kong, begpackers usually stay in Chungking Mansions, arguably the city's most affordable accommodation. Some respondents had a tent so they could camp when they had no money or when the weather was good. This allows them to save money to fund travel. Similar to backpackers, begpackers may travel alone, but may meet other travellers and travel together until their paths separate (Luo, Huang, \& Brown, 2015). This may help reduce some living expenses. In countries in Southeast Asia, especially in rural areas, travellers appear to rely on hospitality of local residents. Respondent 4 stated the following:

In a Muslim country, like Indonesia, people invite in the house. They say it's dangerous to stay in a tent for whites. So, they invite to stay in their houses. In Papua New Guinea people are very open, they also invite into their homes. People help. (R4) 

establishments. Those travelling with camping equipment cooked food on a camping stove. The interviewed begpackers appeared quite resourceful and knowledgeable about local opportunities to save money. Respondents 6, 7 and 8, for example, ate at a Sikh temple in Hong Kong, as the temple provides free vegetarian meals to all visitors.

Begpackers use budget means of transportation to travel between destinations. Low-cost carriers provide means to travel long-distance. They cover distances over land using intercity buses and hitchhiking. At destinations, begpackers use public transportation to get around.

Respondents claimed that they are not very interested in major tourist attractions, preferring to wander around destinations. The following quote represents this perspective: 'I've been on a mountain here. I meet locals. They take me around. They showed me a mountain with the best view on Hong Kong. But I don't know the name of it' (R2). Respondent 8 stated that he finds meeting people more enriching than visiting attractions. Overall, begpackers appear prepared to sacrifice some of their basic needs, such as shelter, food and safety, in order to fulfil selfactualisation (i.e. discover the world), which is one of the higher level needs according to Maslow's hierarchy of needs. Such approach may be seen similar to the original drifters (Cohen, 1973; Weber, 2001).

\section{Conceptualising the begpacker: Leisure, lifestyle, necessity}

While mainstream media (e.g. Grira, 2017; Groundwater, 2017; Pleasance, 2017; Pouget, 2017) may judge begpackers as backpackers who prey on the generosity of the communities they visit to fund their own leisure activities, further analysis reveals the diversity of the begpacking phenomenon. Interviewees were asked to define their style of travel and reflect on their motivations to travel in this way. When these responses are considered in relation to the media perception of begpacking, it is possible to conceptualise begpacking as a phenomenon happening in a zone of overlap between three dimensions: leisure, lifestyle and necessity.

Some regarded their travel as leisure, defining it broadly as 'self-planned travel' (R5). This reflects the representation of begpackers in mainstream media, as conventional Western travellers asking for money to fund their travels. However, interviewees highlighted the difference between their travel style and more traditional modes of travel, which they considered 'boring' (R1), because everything is pre-planned. Begpackers emphasised their own lack of plans and funds when they left home. When asked about what they wished to gain from their travels, all respondents agreed that they wanted to learn about the world, broaden their horizons, gain life experience and self-actualise. One respondent expressed: 'Basically, I want to find myself. Travelling opens a lot of possibilities. I started to love everything. Everything seems brighter now.' (R2). Based on this, the leisure dimension of begpacking introduces a distinction between begpacking as entertainment and as self-actualisation.

The interviewed begpackers generally regarded their style of travel as a lifestyle - some suggesting that they were following a long tradition of travelling and busking, comparing 
themselves to traditional travelling musicians in Europe. While some of them used this type of travel as a temporary means for escapism, others considered it as a more permanent state: 'I wanted to dive into life, I wanted to participate actively in life. I couldn't do that sitting in an office in front of computer... I don't think I travel through countries, I live in the countries I visit' (R8). One respondent explained how he considered this type of travel as his fate or destiny: 'I'd say this travel for me is fate/destiny. This is the real life' (R2). For others, the travelling lifestyle had started out of necessity, as they saw no future in their home countries or could not return home. For the latter group, begpacking was a part of their search for a permanent place to live. This was expressed by the interviewed begpacking couple, when asked to define their style of travel: 'Search for a permanent place to live, to create family and continue living' (R6 and 7). Three respondents (R4, 6 and 7) fled Eastern Ukraine after the armed conflict started in 2014. Originally, they planned to travel until peace was restored. As it became apparent that the conflict was not going to be resolved quickly, they made travelling their lifestyle with little interest in returning home:

I wasn't planning to travel for so long. I flew to Turkey, and then I wanted to go overland to Armenia, Russia and return home to Ukraine. But the war broke out and I lived as a refugee in Armenia.... After Armenia we returned home, then went to Russia. ... After that, I realised that there is absolutely nothing to do at home, it's a sad situation there. So, I took a risk and bought an airplane ticket to Bangkok, Thailand, and that's where I started my long trip. Iflew to Thailand in March, 2015. Before this trip, I normally had some budget, I still had money when I flew to Thailand. As the trip was becoming a long one, I started to think of how to get some extra money. I learnt how to play guitar and started to play. (R4)

The difference in permanency and motivation to engage in the begpacker lifestyle introduces a distinction between begpacking as escapism - understood as a means to get away from routine, and begpacking as escape - understood as fleeing from a dangerous or unpleasant situation.

The necessity of begpacking which is illustrated in the example above constitutes a third dimension. These begpackers travel out of necessity, because they have been displaced due to an armed conflict and cannot return home. Others also travel as begpackers out of necessity, but do so due to lack of economic funds. They would simply not be able to travel otherwise.

Respondents 2 and 8 explained that begpacking was the only option for them to see the world, as it is impossible to save enough money for international travel due to low salaries in Kazakhstan and Ukraine. These differences introduce a distinction to the necessity dimension of begpacking, between lack of funds and being a displaced person.

Despite similarities, the begpacker phenomenon encompasses travellers who vary greatly in terms of motivations, opportunities and reasons for travel. Three dimensions of leisure, lifestyle and necessity are always in play. There is, for example, a big difference between a traveller with dreams of escapism who wants to experience a different part of the world and self-actualise on the cheap, and a displaced person driven to escape his/her home country, who uses begpacking as a means to find a place to live while unable to claim a refugee status. These examples 

narratives we collected from some respondents. Importantly, the three dimensions of necessity, lifestyle and leisure should not be considered as mutually exclusive. It is for example possible for both entertainment and self-actualisation to play a role in particular person's decision to engage in begpacking as a form of travel.

\section{Reactions to Begpackers}

Most passers-by who gave funds to the researcher-begpacker during the social experiments commented that they saw the sign asking to support his travels and wanted to help. Two themes emerged. The first theme was that as a perceived traveller, he may need assistance or be in trouble 'I thought maybe he was in trouble. He is a foreigner. Maybe he lost his passport.' (Tibetan, Age 46) or 'Yes, I read the sign, I just want to help him. He looks a bit sad, might be a bit lonely. A foreigner in my city, I wanted to help.' (Hong Kong, Age 65). Here locals and other tourists show compassion and altruistic behaviour, helping a traveller far from home. The second reason for giving funds was that the researcher-begpacker was contributing to the city atmosphere, adding colour to Hong Kong by playing music. A related reason was that he was playing music rather than just begging. As noted by one donor: 'He is giving his service in exchange for money. He is playing music. So it's good. He is not just begging.' (Hong Kong, Aged 50). There was a general feeling that it is better if the begpacker contributes something, rather than just begging.

To examine whether there was any anti-colonial sentiment alluded to in the mainstream media among the local community about Westerners begbacking (Pouget, 2017), passers-by who donated were asked whether it would make a difference if the begpacker was not Caucasian. In general, the passers-by who gave money stated they would have donated regardless of race. However, several Hong Kong residents expressed distrust of Mainland Chinese and stated that they would be reluctant to give money to a Mainland Chinese begpacker. For example:

Not sure...but he is a white foreigner, easy to spot and distinctive, I guess. We wouldn't give money to Mainlander. We don't know if we can trust. He might make up a story to get money. For this case, he seems like a nice guy and he is playing music in exchange for money. (Hong Kong, Age 65)

Some respondents felt that busking should be of a certain standard to warrant donations. One Hong Kong resident, age 35, watched for some time before commenting to the interviewer 'I didn't want to give him money at the beginning because he is playing so badly. Then I thought, he is at least trying to play even though he is not good, so I gave him money.'

Some passers-by who gave funds commented that they gave funds so that the researcherbegpacker could achieve his life dreams:

I don't see anything wrong with that (begpacking). He wants to see the world, why not. He wants to make that happen, I think that's good for him to pursue his dream to see the world. (Hong Kong, Age 50)

Another stated: 
Why not? He is playing music, showing his skill, making this area lively. He wants to travel. That's good for him. I don't get to see many parts of the world. I can give him some money. (Hong Kong, Age 41)

When asked if it made a difference how the researcher-begpacker will use the money, feelings were mixed. Whether they gave money or not, the large majority of those interviewed believed in the integrity of the researcher-begpacker. About half stated they did not mind how the money is spent. The other half stated the funds should be spent on travel - the reason for requesting the funds. For those who did not give, all of them noticed the researcher-begpacker busking.

Both those who donated and those who did not categorised busking / begging into different types. Backpackers who were just begging were, for the most part, deemed to not warrant funding while those who were giving something back (such as playing a musical instrument) did warrant some support. However, if the busker's performance was not of high quality, then it was perceived they should receive less donations than buskers who were more talented. This demonstrates that residents and other tourists are willing to give if the begpacker is giving back or contributing in some way.

Several reasons were offered by respondents for not donating to the researcher-begpacker. These include personal lack of financial means: 'I am a student still. I don't have extra cash to give to someone.' (Hong Kong resident, Age 27) and that the researcher-begpacker could earn funds by working by other means, without relying on the generosity of others. This reason had two components. Firstly, the researcher-begpacker can earn funds through regular work. The researcher-begpacker did not appear to have any disability: 'I would give money for people who can't work, but he looks normal. He can do something. He is not helpless' (UK, Age 26). Secondly, some passers-by who did not donate money perceive international travel as a luxury. They argue that if people want to travel internationally they should work, save up and then travel. This is epitomised in the following:

No, I don't (donate). I find travelling is something you can live without, it's a:, luxury in a sense. I have to work hard to save money if I want to travel. It is too easy for him to just play music to get money to travel. He can work and save money for travelling. He is not handicapped. Philippines, Age 40

This sentiment seems to correspond to criticisms about begpackers seen on social media and the mainstream media. During the social experiments no passers-by expressed negative feelings to the researcher-begpacker directly neither verbally nor in their actions, and only expressed negative views when asked by the researcher-observer.

Returning to the interviewed begpackers, they also generally expressed that they had perceived more positive than negative reactions from local residents. Most often they would simply be ignored by passers-by. Nevertheless, all respondents had also faced some negative reactions. One respondent provided the following example: 
One lady started screaming at me: 'People here are not rich and what do you do? You just ask for money for your vacation. I have a baby and I have a husband. I don't do it, so why do you do it?' And she started swearing (R1).

Similarly, respondents had more positive than negative experiences with local law enforcement, at least in Hong Kong. Police are generally reluctant to remove begpackers from the streets, despite the fact that begging breaches the Summary Offences Ordinance. There was even an example where police sided with a begpacker, rather than a local resident in a dispute:

There is one place that we really like... but there is one man working there, who doesn't like buskers and he always calls police ... Even when the police arrive, they say: 'Don't pay attention to that crazy guy'. Police find it shameful that some locals are negative... (R6 and 7)

When asked about news articles and social media posts criticising begpacking, respondents commented that they are young, do not have money nor opportunities to earn enough back home and want to see the world - they do not disturb anyone and giving money is purely voluntary.

\section{Discussion}

The conceptualisation of begpackers illustrates the heterogeneity of the people in this travel category. In contrast to the image of begpacking promulgated by the mainstream news, the begpackers interviewed for this study did not generally appear as egoistic rich white kids imposing colonial and exoticised views of Asia (Pouget, 2017). At least in Hong Kong, they appear to come from relatively poor and unstable former Soviet countries. This makes arguments for begpackers being entitled and begpacking being colonialist flawed. Begpackers' wanderlust, lack of planning and inability to fund conventional travel, brings them closer to 'tramps' and 'drifters' than more institutionalised backpackers (Cohen, 2004). Begpackers perceive themselves as free-spirited travellers: 'drifters' in Cohen's (1973) terminology. Figure 4 places begpackers on a continuum from tramping to conventional tourism, in which begpackers occupy a space between tramps and backpackers, depending on their positions within the three dimensions presented earlier, namely necessity, lifestyle and leisure.

Figure 4: Begpacking's position on travel style continuum

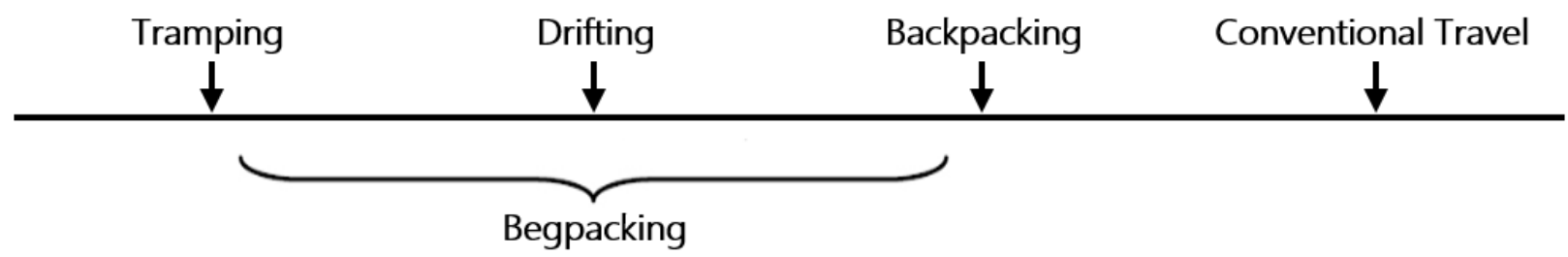

Source: Authors

Begpackers represent a unique and interesting group of travellers that may further add to the diversity of tourist typologies, as well as to understandings of the differences between tramps, 

development of the conceptualization of the begpacker introduced in this paper.

Most previous literature on the contact between begging and tourism focusses on tourists' perceptions of begging by local community members at destinations. This research is different in that it addresses tourists who are doing the begging. Using Andriotis' (2016) typology of beggars, begpackers fall into all types of beggars: several begpackers were classic beggars who waited patiently for donations from passers-by; several were Andriotis' table-to-table beggars, selling small items such as photographs while a third type were buskers, playing musical instruments for money. Qiao et al. (2017) typecast beggars by demographics, approach and technique. The begpackers in this research were found to be demographically similar - relatively young and from the countries of the former Soviet Union. The begpackers were passive in their approach, with signs asking for donations or an open musical instrument case or bucket indicating that passers-by could donate. The techniques used for begging varied from simply standing to selling items to musical performances.

As in Andriotis (2016) study, the most common reaction to both the begpackers and the researcher-begpacker in the social experiment was apathy. Regardless of whether the passers-by liked the begpackers' presence or not, and hence, whether they experienced an injustice, the default behavioural reaction was to do nothing (Tyler, 2008). As reported in the social experiment, some of this apathy is a result of the passers-by not being able to financially contribute to the begpacker, even if they wanted to, due to lack of income. A smaller segment were sympathetic to begpackers such as residents who stopped to talk to or listen to the music of the begpackers. Supportive tourists gave money voluntarily to the begpackers as well as in the social experiment. While all begpackers reported instances of negative reactions, these were rare. During the experiment, negative opinions were expressed only during interviews with the researcher-observer.

Begpackers do not perceive begpacking as being unethical as there was no harassment and donating is voluntary. While most begpackers perceive busking or selling photographs as more worthy of donations than begging, begpackers felt the decision of whether to donate is ultimately the decision of the passers-by. In addition, buskers providing music were adding to the street atmosphere. Some local residents agreed that playing music or selling photographs is more deserving of donations than simply begging. They perceive it as an exchange of money for service. While for some residents level of skill in the begpacker's chosen activity may play a role in the decision to donate or how much to donate, others are quite happy to contribute to the realisation of a begpacker's dream: to travel. This is akin to philanthropy, while the former is representative of equity theory.

Equity theory provides a useful lens with which to understand the begpacking phenomenon. Interactions between tourists and host are often evaluated at a personal level as the results of the ratio of what one party receives relative to their contribution. If the benefits of the personal interaction is greater than the cost of the interaction, the exchange is perceived as equitable (van den Bos, 2001). The begpackers argued that they were, through the means at their disposal, trying to contribute to the local community. However, a segment of the local interviewees saw 
the interaction between begpacker and the local community as unequal, with the begpacker receiving money from the local community, rather than contributing to the local economy (Walster et al., 1973). There is a perception that begpackers are circumventing the 'rules' and hence were perceived by some local residents as causing harm. For many hard-working locals, the opportunity for international travel involves hard work and sacrifices. Begpackers are 'taking a shortcut'. Some members of the local community see this as unfair and are disgruntled. Based on this, some respond with mild irritation, while others respond with aggression, as evidenced in social media responses to stories about begpackers. The chances of getting a more negative response seem to be larger if the begpacker is not contributing, for example, in the form of busking. Meanwhile, begpackers stress that donating to them is voluntary and that they meet and interact with local residents which contributes to cultural exchange. In these situations, begpackers were enacting the common neutralization technique of denying any injury / negative consequence of their begpacking (Chatzidakis et al., 2006). The interactions between begpackers and the community can be regarded as an intersection between the begpacker activity and the host emotion. This interaction elicits a response and potentially a donation from the host to the begpacker. This intersection and the potential responses are visualised in Figure 5. The distinction between reactions to begging and busking are provided. The figure demonstrates that donations may be understood as a philanthropic action resulting from a sense of empathy or compassion, as an equitable exchange or a combination of two. The figure also illustrates the difference between the perception of begpackers represented in mainstream media (the lower half of the figure) and many of the more positive responses that our interviews revealed (upper half of the figure).

Figure 5: Community response to begpacking 


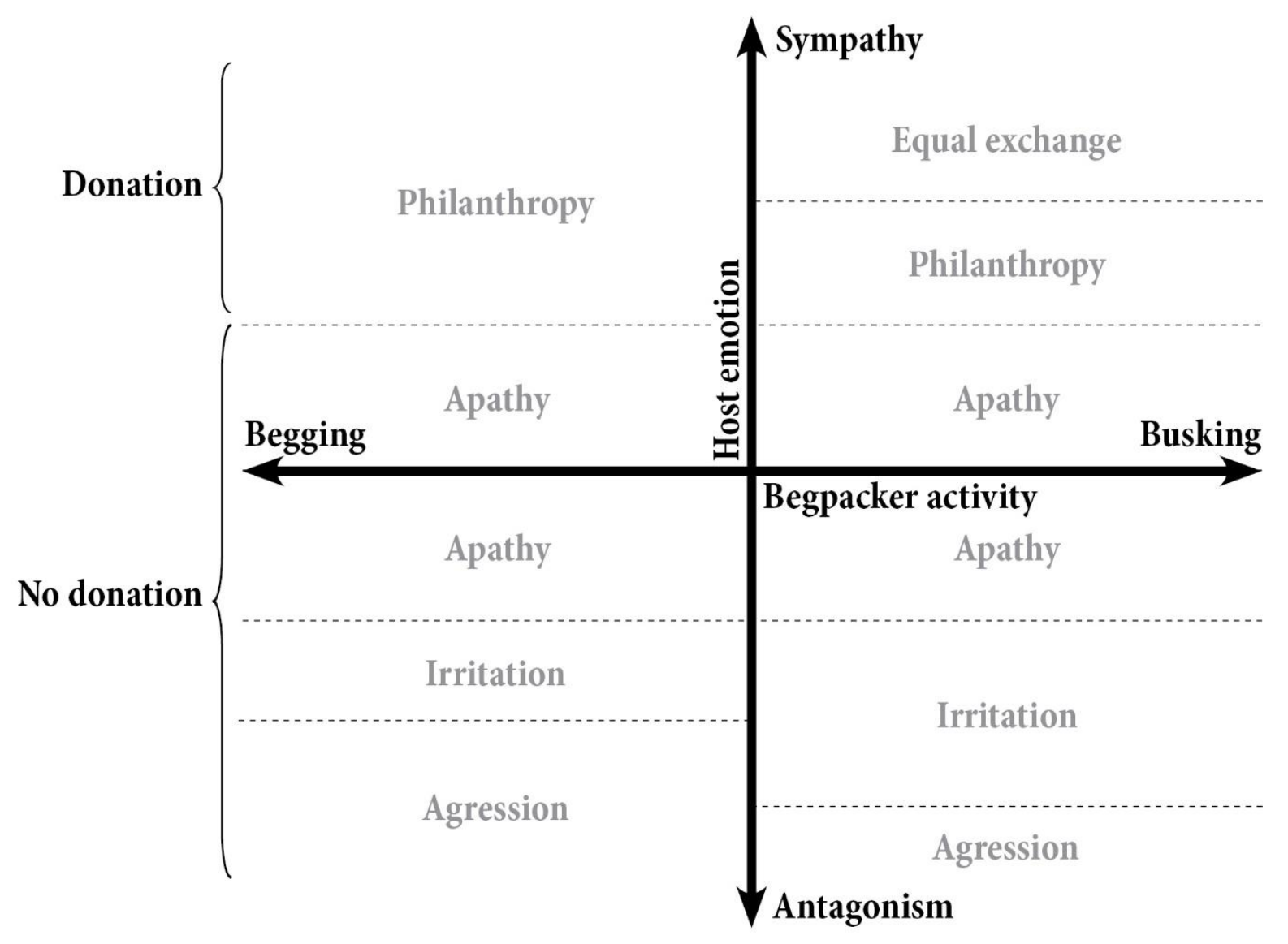

Source: Authors

\section{Conclusions}

'Begpacking' is a portmanteau of 'begging' and 'backpacking'. The term has been used on social and mainstream media to refer to travellers who ask passers-by to help fund their travel by begging for donations, selling trinkets or photographs or busking. The media has condemned these tourists, claiming they are entitled, rich white kids exploiting the generous hospitality and altruistic nature of their Asian hosts (Grira, 2017). This exploratory study of begpackers has found that the media might have misinterpreted the begpacking phenomenon in some respects, as the findings of the present study demonstrate. Travellers who fall within the begpacker designation are a highly heterogeneous group. The heterogeneity of begpackers comes from their differing motivations, opportunities and socio-economic background.

Interviews with begpackers and a social experiment involving local residents allowed for a conceptualisation of begpacking based on three dimensions: leisure, lifestyle and necessity. The image presented by the media depicts begpackers as travellers who want to be entertained, travel on the cheap and escape routine life. However, some of the begpackers interviewed for this study were uprooted due to unrest in their home country, wanted to escape tough living conditions in the home country or use travel to self-actualise. Interestingly, somewhat challenging Maslow's 
hierarchy of human needs, the latter group are ready to risk the basic needs of food, shelter and safety in hopes to achieve self-actualisation.

The interaction between begpackers and local residents has been conceptualised based on the intersection of emotional responses from the host and the activity performed by the begpacker. Emotional responses range from sympathy, through apathy to irritation and aggression.

Depending on whether begpackers simply ask for money with a sign, sell trinkets or play music, the decision to donate can be philanthropic (helping a person out of a goodwill) or an application of equity theory (exchanging benefits).

The study is limited by its exploratory nature, involving interviews with a limited number of begpackers in one context, Hong Kong. The begpacker interviews were supplemented with a social experiment whereby the research team simulated a begpacking situation to gain interviews with members of the local community and other tourists. While Hong Kong is a destination that has reported instances of begpacking, it would be interesting to compare our findings in the Hong Kong context with similar findings in other destinations where begpacking has occurred, for example in South and South-East Asia, where the level of socio-economic development is low and thus travellers begging or busking on the streets may be viewed differently. Future research may also focus on understanding roles that perceived equitable exchange and sense of compassion/empathy play in donating, not only to begpackers, but also to other types of buskers. 


\section{References}

Adams, J. S. (1965). Inequity in social exchange. Advances in experimental social psychology, 2, 267-299.

Adler, J. (1985). Youth on the road: Reflections on the history of tramping. Annals of Tourism Research, 12(3), 335-354. doi: https://doi.org/10.1016/0160-7383(85)90003-9

Adriaenssens, S., \& Hendrickx, J. (2011). Street-level Informal Economic Activities: Estimating the Yield of Begging in Brussels. Urban Studies, 48(1), 23-40. doi: doi:10.1177/0042098009360688

Andriotis, K. (2016). Beggars-tourists' interactions: An unobtrusive typological approach. Tourism Management, 52, 64-73. doi: http://dx.doi.org/10.1016/j.tourman.2015.06.006

Ap, J. (1990). Residents' perceptions research on the social impacts of tourism. Annals of Tourism Research, 17(4), 610-616. doi: http://dx.doi.org/10.1016/0160-7383(90)90032$\underline{\mathrm{M}}$

Brito, O. (2013). Definitional Paradox and legal heterogeneity: towards a comprehensive and operational definition of begging. Asian Social Work and Policy Review, 7(3), 228-241.

Burnstein, E., \& Katz, S. (1972). Group decisions involving equitable and optimal distribution of status. In C. G. McClintock (Ed.), Experimental Social Psychology (pp. 412-448). New York: Holt, Rinehart \& Winston.

Chatzidakis, A., Hibbert, S., \& Smith, A. (2006). 'Ethically Concerned, yet Unethically Behaved': Towards an Updated Understanding of Consumer's (Un)ethical Decision Making. Advances in Consumer Research, 33(1), 693-698.

Cohen, E. (1973). Nomads from Affluence: Notes on the Phenomenon of Drifter-Tourism. International Journal of Comparative Sociology, 14(1-2), 89-102.

Cohen, E. (2004). Backpacking: Diversity and Change. In G. Richards \& J. Wilson (Eds.), The Global Nomad: Backpacker Travel in Theory and Practice (pp. 43-59). Clevedon: Channel View Publications.

Cohen, E. (2018). Backpacker enclaves research: achievements, critique and alternative approaches. Tourism Recreation Research, 43(1), 105-116.

Collins-Kreiner, N., Yonay, Y., \& Even, M. (2018). Backpacking memories: a retrospective approach to the narratives of young backpackers. Tourism Recreation Research, 1-4.

Dayour, F., Kimbu, A. N., \& Park, S. (2017). Backpackers: The need for reconceptualisation. Annals of Tourism Research, 66, 191-193.

Golafshani, N. (2003). Understanding reliability and validity in qualitative research. The qualitative report, 8(4), 597-606.

Grira, S. (2017). 'Beg-packers': White tourists who beg in southeast Asia. http://observers.france24.com/en/20170410-\%E2\%80\%9Cbeg-packers\%E2\%80\%9Dwhite-tourists-who-beg-southeast-asia

Groundwater, B. (2017). 'Begpackers' - backpackers begging for money: Why travel's generation of entitlement is a disgrace. http://www.traveller.com.au/its-ridiculous-begpackers-whytravels-generation-of-entitlement-is-a-disgrace-gvnhp1

Grundy, T. (2017). 'Travel beggars' appear in poorest parts of Hong Kong, outraging critics. Retrieved from https://www.hongkongfp.com/2017/04/14/travel-beggars-appear-poorestparts-hong-kong-outraging-critics/.

Hampton, M. P. (1998). Backpacker tourism and economic development. Annals of Tourism Research, 25(3), 639-660. doi: https://doi.org/10.1016/S0160-7383(98)00021-8 
Harrill, R. (2004). Residents' attitudes toward tourism development: A literature review with implications for tourism planning. Journal of Planning Literature, 18(3), 251-266.

Henry, E. (2009). The Beggar's Play: Poverty, Coercion, and Performance in Shenyang, China. Anthropological Quarterly, 82(1), 7-35.

Kuzel, A. J. (1992). Sampling in qualitative inquiry. In B. Crabtree \& W. Miller (Eds.), Doing Qualitative Research (pp. 33-45). California: SAGE.

Kvale, S., \& Brinkmann, S. (2008). Interviews: Learning the Craft of Qualitative Research Interviewing (2nd ed.). Los Angeles: SAGE Publications, Inc.

Loker-Murphy, L., \& Pearce, P. L. (1995). Young budget travelers: Backpackers in Australia. Annals of Tourism Research, 22(4), 819-843. doi: https://doi.org/10.1016/01607383(95)00026-0

Lozanski, K. (2013). Encountering Beggars: Disorienting Travelers? Annals of Tourism Research, 42, 46-64. doi: http://dx.doi.org/10.1016/j.annals.2013.01.004

Luo, X., Huang, S., \& Brown, G. (2015). Backpacking in China: A Netnographic Analysis of Donkey Friends' Travel Behaviour. Journal of China Tourism Research, 11(1), 67-84. doi: 10.1080/19388160.2014.908757

Maxwell, J. A. (2004). Qualitative Research Design: An Interactive Approach (2nd ed.). Thousand Oaks, CA: SAGE Publications, Inc.

Mohsin, A., \& Ryan, C. (2003). Backpackers in the Northern Territory of Australia-motives, behaviours and satisfactions. International Journal of Tourism Research, 5(2), 113-131. doi: $10.1002 /$ jtr.421

Nok, L. C., Suntikul, W., Agyeiwaah, E., \& Tolkach, D. (2017). Backpackers in Hong Kongmotivations, preferences and contribution to sustainable tourism. Journal of Travel \& Tourism Marketing, 34(8), 1058-1070.

Patton, M. Q. (2001). Qualitative Research \& Evaluation Methods (3rd ed.). Thousand Oaks, CA: SAGE Publications, Inc.

Pleasance, C. (2017). Shameless rise of the 'beg-packers': Astonishing phenomenon of Western backpackers who beg for money to fund their travelling as they journey through some of the world's poorest regions. http://www.dailymail.co.uk/news/article-4400790/RiseWestern-backpackers-begging-fund-trip.html

Pouget, J. (2017). The Rise Of 'BegPacking' Travelers Prompts A Social Media Backlash. http://www.konbini.com/us/lifestyle/what-is-beg-packing-trend-social-media-backlash/

Qiao, G., Chen, N., \& Prideaux, B. (2017). Understanding interactions between beggars and international tourists: the case of China. Asia Pacific Journal of Tourism Research, 22(3), 272-283. doi: 10.1080/10941665.2016.1233891

Richards, G. (2015). The new global nomads: Youth travel in a globalizing world. Tourism Recreation Research, 40(3), 340-352.

Richards, G., \& Wilson, J. (2004). The Global nomad: Motivations and Behaviour of Independent Travellers Worldwide. In G. Richards \& J Wilson (Eds.), The global nomad (pp. 14-39). Clevedon: Channel View.

Russel, B. H. (2006). Unstructured and Semi-structured Interviewing. In B. H. Russel (Ed.), Research Methods in Anthropology. London, UK: Sage.

Seidman, I. (2005). Interviewing as Qualitative Research: A Guide for Researchers in Education and the Social Sciences (3rd ed.). New York: Teachers College Press.

Simpson, P. (2011). Street Performance and the City. Space and Culture, 14(4), 415-430. doi: doi: $10.1177 / 1206331211412270$ 
Smith, P. K. (2005). The Economics of Anti-Begging Regulations. American Journal of Economics \& Sociology, 64(2), 549-577. doi: 10.1111/j.1536-7150.2005.00379.x

Tyler, T. R. (2008). Social Justice Blackwell Handbook of Social Psychology: Intergroup Processes (pp. 344-364): Blackwell Publishers Ltd.

Uriely, N. (2001). 'Travelling workers' and' working tourists': variations across the interaction between work and tourism. The International Journal of Tourism Research, 3(1), 1-8.

van den Bos, K. (2001). Fairness heuristic theory : Assessing the information to which people are reacting has a pivotal role in understanding organizational justice. Theoretical and cultural perspectives on organizational justice, 63-84.

Veal, A. J. (2006). Research methods for leisure and tourism: A practical guide (3rd ed.). Harlow: Prentice Hall.

Walster, E., Berscheid, E., \& Walster, G. W. (1973). New directions in equity research. Journal of Personality and Social Psychology, 25(2), 151-176.

Wardhaugh, J. (2009). Regulating social space: Begging in two South Asian cities. Crime, Media, Culture, 5(3), 333-341. doi: doi:10.1177/1741659009346020

Weber, K. (2001). Outdoor adventure tourism: A review of research approaches. Annals of tourism research, 28(2), 360-377.

Weber, L., \& Bowling, B. (2008). Valiant beggars and global vagabonds. Theoretical Criminology, 12(3), 355-375. doi: doi:10.1177/1362480608093311

Woosnam, K. M., \& Norman, W. C. (2010). Measuring residents' emotional solidarity with tourists: Scale development of Durkheim's theoretical constructs. Journal of Travel Research, 49(3), 365-380. 